\title{
The Importance of Freedom of Religion as a Foundamental Human Right
}

\section{Evalda Jera, PHD Candidate}

Europian University of Tirana

Email: evaldajera@yahoo.com

\author{
Doi:10.5901/mjss.2015.v6n4s3p357
}

\begin{abstract}
The purpose of this paper is to present the importance of freedom or religion as a foundamental human right. Freedom of religion is one of the balancing factors in the life of the individuals, it is the most magnificent human identity which aims to achieve the purity of soul. Religion elevates the man to the highest human virtues and moral, helping for the normal functioning of society. This paper analize the fact that freedom of religion and beliefis is a basic right of every human being, it is an universal human right that worth for all persons equally anywhere, regardless of who they are, where they live, age, sex, race or ethnicity and what they believe or do not believe. Freedom of religion or belief is protected by Article 9 of the European Convention of Human Rights and other acts. So clearly religion has been an important source of human rights. Modern human dignity is based on the religious notion of holiness personified of every human being as a right universal human right, so freedom of religion and belief has its defense to respect the diversity because this contributes directly in the democracy, development, rule of law, peace and stability. So belief may not be limited under no circumstances. States should treat all individuals equally, without discrimination based on religion or belief.
\end{abstract}

Keywords: religion, law, society, human rights

\section{Introduction}

Freedom of religion is the starting point of civil and political liberties. Historical experience has shown us that the lack of religious freedom can lead to quite serious consequences for the political stability of a country and the international peace (Sinan, 2010). Freedom of conscience means the right to trust. Thus, freedom of conscience and religion is a fundamental right of every human being. Violations of freedom of religion and belief often represent early indicators of potential violents and conflicts. Religion and faith can determine as one of the main links of life, it can define as a behavioral norm by which individuals can see the personal and social consequences of their actions. Also adding further definition we can say that religion is a system of thought, a feeling of specific action performed by a group of believers and that gives members a goal commitment, being a speaker model by which individuals can be related to their group and their universe. It is one of the balancing factors in the life of the individuals, it is the most magnificent human identity which aims to achieve the purity of soul. Religion elevates man to the highest human virtues and moral, helping so the normal functioning of society. Religion and faith as teaches man linked to that never loses if his faith will be okay and if they act according to the code (Fagaro, 2007).

\section{Analysis}

The right of freedom and conscience is a fundamental right of every human being and as an universal human right, freedom of religion or belief has essentially the respect for diversity, which directely contributes to democracy, in development of the rule of law and stability. Violations of freedom of religion or belief may aggravate the situation being descended with intolerance and can often trained indication of violence that leads in a potential conflict. Religion for centuries was the regulator of social and political life where the Bible, the Qur'an and the Civil Code were the same that determine the rules and norms which should be respected in a society. Religion makes one of the most powerful forces, with great impact on human society. Religion and faith are based on the norms and rules which well-define the behavior. The main element of all religions is the concept of a relationship. The relationship may include one or more people can be physical or spiritual, dynamic or static, but can also be real or imaginary. Only a small part of the religious right has to do with rituals, worship and personal ethics, the rest has to do with the social order, rules of conduct that must follow each subject for a community in harmony. So as quoted above religion and faith make up one of the most powerful forces, with more impact on human society. Religion is an important aspect of social life but on the other hand the social dimension is 
an important part of the religion itself. At its simplest any religion can be seen as a belief system. This system can affect the values, laws, customs, rituals and general patterns of behavior. Faith can affect the individual, group, society or even the nation itself, playing an essential role. Faith can dictate acceptable set of standards or rules of conduct and those who want to remain in that society should support these standards. Freedom of religion belongs to the realm of inner experiences of the individual (Nawicki, 2003). Thus individuals and societies should be free to form their belief as a fundamental right. Through religion society reflects itself to its members (Durkheim, 2007) Human society during its evolution has known various forms of belief either mono or polytheistic, the difference between them is that if faith is directed toward one or more of divinity. Well bully all persons have the right to take and express their religion or belief either individually or in community with others or to express trust in public or private worship, without the fear of discrimination or violence. The Europian Union and its member states are committed to respecting, protecting and promoting freedom of religion or belief (EU Guidelines on the Promotion and Protection of the Freedom of Religion or Belief, 2013). In Europe, freedom of religion or belief is protected by Article 9 of the European Convention of Human Rights and other acts. Thus, freedom of religion or belief as a basic adequately that needs to be exercised by everyone everywhere under the parimtt equality, non-discrimination and universality. Europian Union is impartial and does not support any particular religion or belief.

1. Religion is a relationship that is placed between a person and one or more divinities or supernatural powers and peoples who perform the same cult.

2. Religious norms are a set of rules implementing and practicing behavior which can bring order and harmony in society, which also would enable functioning of the society in an organized and systematic manner.

3. The right to freedom and conscience is a fundamental right of every human being and as a universal human right, freedom of religion or belief has essentially respect for the diversity.

4. The violation of freedom of religion or belief may aggravate the situation being descended with intolerance and can often trained into potential conflicts.

Now religion has become a factor of stability in society it is also an important factor of social integration. So it feeds its members with the values and norms as well as helping their consensus for moral issues (Stone, 2007). People in life are often faced with cases where hidden violation of law and a power abuse, realizes the different interests at the expense of others. In all such cases of human morality is crucial. God judges on all the works of men, the true goals, our desires and feelings. Belief in this form of justice encourages man to every good work he has done and does, because the hypocrisy and autocracy will be punished. This is another crucial role of religion and faith, awakening the clean conscience and direction the humanity with their thoughts and actions towards the positives. Well we know that religious institutions, sowing the seeds of faith, justice and solidarity, cultivating peace. Today the society is increasingly chaotic, been unable to escape the phenomenon that tends to isolate and alienate the man leaving alone and without support. Thus emerges the primary role of religion as a major social factor of hope, faith, courage positive social and source of energy, in which the individual finds support, fulfilling one of his natural rights, thus establishing a fair balance between the religious and social elements. Today's society is keen contemporary human right individualization. The twist is defined in religious terminology as a secular phenomenon and on the other hand expresses the socialization of society through religion and belief. Religious feelings are feeling social, are community feelings, being realized not only individually, but also as a social group together in associations, religious organizations and institutions. Religious institutions in modern times, have a specific social function, as a way to control the spiritual and moral of humans. Civil society has valued skills that religion unifying link between people of the same faith. Religion elevates man with high human virtues and moral, to strengthen, enrich and exalt the soul. It is a tool or way of continuous improvement and development, bringing together people between them, elevates the sense of protecting each other, develop personal freedom and strengthens society. The right of freedom and belief is "far-reaching and deep", it is a favorable basic freedom that includes all religions and beliefs (United Nations Human Rights Committee General Comment). So religion and faith educate people with high ideals. It affects the formation of the unity of the members of society through control and enforcement preaching unique values and norms. Also it promotes group solidarity. Religion has a great influence on the whole life of man in particular in his bodily integrity and spiritual. Without the right to trust the people have the right attitude towards human beings and society. The relationship between law and religion are continuously transformed throughout history. According to natural religious law religion is a law driven by a belief in God or divine forces, morality and legality which are embedded in religion, that means that law and religion has been not completely separated. Secularization of law has advanced since the sixteenth century through revolutions, these revolutions have changed the structure of western law through greater institutional separation of church law but not drastically reduced the importance of religion in law. The complex interactions and mutual in many aspects between law and religion deserve special attention because of their sociopolitical importance. Although there are discrepancies institutional, organizational and 
cultural between political regimes and religions, between neo-liberalism religion transnational and international expansion or globalization is a remarkable as a powerful force in sociopolitical legal. For more today the society is critical to what portrays religion, viewing fenw and religious law as largely non-modern phenomena and social primitive that are driven to make up an image of savagery and terrorism. Gradually came partial divorce of law from religion and its construction as a "professional autonomous area has adopted the law power (Thomanikaj, 2015). Law and Religion are infinitely dynamic spaces which have often limiting institutions, indicating in society, and imposed a heavy political power. States have the primary duty to protect all persons living on their territory, including belivers, atheist minorities. States should treat all individuals equally, without discrimination based on religion or belief of their.

\section{Conclusion}

So clearly religion has been an important source imposed in human rights. Modern human dignity is based on the religious notion of holiness personified of every human being as a universal right. Freedom of religion and belief has its defense to respect the diversity because this contributes directly in the democracy, development, rule of law, peace and stability. Freedom of religion and beliefis a basic right of every human. This is an universal human right that worth for all persons equally anywhere, regardless of who they are, where they live, age, sex, race or ethnicity, and what they believe or do not believe. Beliefs not may be limited under no circumstances (European Union Guidelines on the Promotion and Protection of Freedom of Religion or Belief). Each limitation of freedom to manifest religion or belief, should be exceptional and should be in accordance with international standards (An information Booklet Presented by institute on religion and public policy, Know your right, What is freedom of Religion, 2014). But around the world, freedom of religion is in attack, with severe restrictions on growth in all five major regions of the globe. People would do more to work together to turn the rising tide of religious repression and to strengthen the universal right of religious freedom for all. Firstly, they can understand the nature of the right of religious freedom and take action against persistent threats to this right, they can implement these principles of religious freedom, while respecting the rights of all faiths and beliefs. Finally, they can work together, people of all faiths to promote and protect freedom of religion and tolerance for all the domestic and international level. . So clearly religion has been an important source of human rights. Modern human dignity is based on the religious notion of holiness personified of every human being as a right universal human right, so freedom of religion and belief has its defense to respect the diversity because this contributes directly in the democracy, development, rule of law, peace and stability. So belief may not be limited under no circumstances. States should treat all individuals equally, without discrimination based on religion or belief.

\section{References}

Article 26 of the ICCPR 1966 - International Covenant on Civil and Political Rights, Articles 2, 4.18, 20, 24, 26, 27

Article 18, Universal Declaration of Human Rights;Article 18 International Covenant on Civil and Political Rights;European Union Guidelines on the Promotion and Protection of Freedom of Religion or Belief.

An information Booklet Presented by institute on religion and public policy,(2014) Know your right, What is freedom of Religion.

Council of the European Union, (2013), EU Guidelines on the Promotion and Protection of the Freedom of Religion or Belief, LouxembourgForeing Affairs Council Meeting.

Durkheim, Book 3, 1965 Chapter 4;taken from Merdith B MC Stones;Religion Social Context;Logos-A 2007 kapitulli6

European Union Guidelines on the Promotion and Protection of Freedom of Religion or Belief

Farago, F., (2007), Christianity, Judaism, Islam and Western thought, freedom for publication Classifieds

Nawicki, M. . (2003). About the European Convention on Human Rights; Tirana

Sinan, G., (2012). Freedom of thought, conscience and religion. Tirana

Stones, M.. (2007), Religion social context; Centre for Public Administration Research, Logos-A.

Thomanikaj, R,. Religion and legal law, 18janar2015 http://www.gazetatema.net/web/2015/01/18/feja-dhe-ligji-juridik/ 